of the back and simultaneously from the rest of the body surface. Sweat obtained by another method? and for shorter time-periods gave similar results. Measurement was made of sweat volume, $p H$, sodium and potassium. Samples were acidified to $p \mathrm{H}$ 4.0 with $1 \mathrm{~N}$ hydrochloric acid and assayed immediately or frozen to preserve activity. Sweat was tested in volumes of $1 \mathrm{ml}$. or less for choline-ester activity by bioassay on the heart of Venus mercenaria according to Welsh's method ${ }^{8}$ and occasionally, when feasible, on the eserinized frog rectus muscle?

Two inactivation procedures used on each sample distinguished choline-ester activity from that of choline and inorganic ions. Activity was abolished by boiling for $15 \mathrm{~min}$., at $p \mathrm{H} 12 \cdot 0$, after addition of sodium hydroxide but preserved after boiling at acid $p \mathrm{H} 4.0$ (ref. 9). In the second procedure the activity was destroyed on incubation for $1 \mathrm{hr}$. with $0.5 \mathrm{mgm}$. of commercially purified bovine erythrocyte cholinesterase (ACHE) in buffer at $p \mathrm{H}$ 6.8. $p \mathrm{H}$ moasurements were made with a glass electrode.

Fig. 1 shows an example of the activity found in swert from a representative fibrocystic patient. The average choline-ester activity for the sixteen fibrocystic patients expressed as acetylcholine was 0.075 $\mu \mathrm{gm} . / \mathrm{ml}$. of sweat (range $0.01-0.25 \mu \mathrm{gm} . / \mathrm{ml}$.). The corresponding figure for the thirteen control patients was $0.0065 \mu \mathrm{gm} . / \mathrm{ml}$. (range $0.002-0.02 \mu \mathrm{gm} . / \mathrm{ml}$.). Five fibrocystic patients gave very high values averaging $0.19 \mu \mathrm{gm} . / \mathrm{ml}$. Some scatter appears in the data from the disease group. Also overlap occurs between groups as one fibrocystic failed to give levels higher than $0.01 \mu \mathrm{gm} . / \mathrm{ml}$. while two non-fibrocystics presented levels of 0.015 and $0.020 \mu \mathrm{gm} . / \mathrm{ml}$. Levels tended to be constant on retesting the same individual and did not appear to be related to sweat volume or $p \mathrm{H}$.

Our work has not been extended to adults or to infants, nor is it controlled for variable degrees of acclimatization or for the finer physiological parameters of sweat collection. The relationship of the findings to function of sweat glands therefore remains to be clarified. Two previous reports describe acetylcholine in sweat from normal individuals in levels estimated at $0.001-0.002 \mu \mathrm{gm} . / \mathrm{ml}$. (ref. 10). The presence of this neurohumor in remarkably higher amounts in the sweat of fibrocystic patients is being investigated.

Edward L. Eykrman

ROBERT J. HURLEY

RICHaRd L. Irwin

Applied Clinical Neuropharmacology Section, Medical Neurology Branch,

National Institute of Neurological Diseases and Blindness,

Bethesda 14,

Maryland.

'Farber, S., Amer. Med. Assoc. Amer. J. Dis. Child., 64, 953 (1942).

${ }^{2}$ Lancet, ii, 955 (1959).

${ }^{3}$ Dische, Z., Fed. Proc., 19, 904 (1960).

'diSant'Agnese, P. A., Rep. Eighteenth Ross Pediatric Res. Conf., 45 (Ross Laboratories, Columbus, Ohio, 1956).

${ }^{5}$ Roberts, G. B., Lancet, $\mathrm{ii}, 964$ (1959).

'Schwachman, H., and Leubner, H., Adv. in Pediatrics, 7, 249 (Year Book Pub., Inc., Chicago, 1955).

'Barbero, G. J., Kim, I. C., and MeGavran, J., Pediatrics, 18, 189 (1956).

${ }^{8}$ Welsh, J. H., and Twarog, B., in Methods in Medical Research, 8 , 187 (Year Book Pub., Ine., Chicago, 1960).

- MacIntosh, F. C., and Perry, W. L., in Methods in Medical Researeh, 8, 78 (Year Book Pub., Inc., Chicago, 1950).

${ }^{10}$ Magay (1935) and Inouye (1949), eited by Kuno, X., in Human Perspiration, 246 (Charles C. Thomas, Springfield, Illinois, 1956).

\section{Types of Cell in Ascites Tumours}

The mouse tumour MCIM (Klein) exists in two sub-lines, the $M_{S S}$, which only grows in the solid form, and the $M_{A A}$, which grows as an ascites tumour and also in solid form, designated $M_{A S}$. The difference between the behaviour of the sub-lines is as yet unexplained in terms of cell structure. Bergstrand and Ringertz have recently found no constant difference on examination with the electron microscope ${ }^{1}$. These tumours have been investigated recently by means of the aniline-blue staining technique ${ }^{2}$.

It has been found that solid tissue cells, including those of solid tumours, show a blue rim- or surfacestaining which is believed to be associated with staining of the common part of the cell walls of adjacent cells which lie between the electron-dense cell membranes. In the $M_{S S}$ tumour such staining is seen in fresh preparations and in sections. The fresh ascites cells of the $M_{A A}$ tumour, like all ascites tumour cells examined, fail to stain at all with the aniline-blue reagent, and stand out as clear, refractile spheres in the blue solution. However, there are also present in the fluid, and sometimes loosely adherent to the peritoneum, small compact masses of cells which, when washed to remove loosely attached free cells, are firm in consistency and show a blue staining surface which may be thick and irregular.

When fresh preparations of the $M_{A S}$ tumour are so treated, it is found that both types of cell are present but in different proportions. There is, in young tumours, a preponderance of solid tumour masses which show blue-staining surfaces, with isolated pools of 'free' cells which can readily be washed out from the tissue and which fail to stain. It appears, therefore, that tumours of either type derived from the $A$ A sub-line contain both elements, the predominating form depending on the environment. This accounts for the appearance of apparently typical 'ascites' cells in the $M_{A S}$ tumours examined by Bergstrand and Ringertz. The softening found in the centre of older $M_{S S}$ tumours is probably due to the cell degeneration so commonly found; in the $M_{A S}$ tumours there may, in addition, be a predominance of 'free' cells in such areas.

Whether the two forms of cell breed true or whether the surface changes are reversible is not yet clear. Further investigations into this and into the reason for the failure of the free ascites cells to stain with aniline-blue are in progress.

JoHN O. LAws

Department of Experimental

Pathology and Cancer Research, School of Medicine, Leeds, 2.

1 Bergstrand, A., and Ringertz, N., J. Nat. Cancer Inst., 25, 525 (1960). 2 Laws, J., and Stickland, L. H., Exp. Cell Res., 24, 240 (1961).

\section{BIOLOGY}

\section{Feeding Habit of Some Central African Freshwater Fishes}

Fishes of the family Citharinidae, belonging to the genera Phago Steind., Eugnathichthys Blgr. and Belonophago Gilt. (Figs. 1-2), together forming part of the sub-family Ichthyoborinae, have an extremely specialized and curious feeding-habit, boing, namely, fin-eaters. 